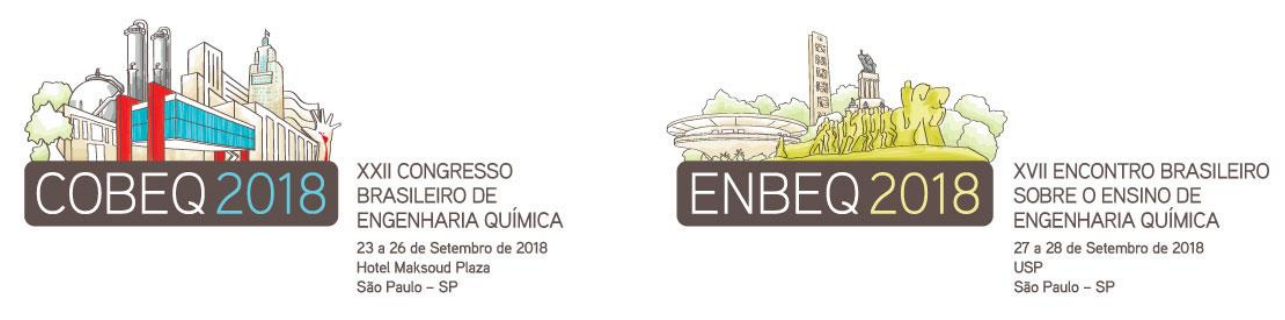

\title{
COMPARATIVE STUDY ON PRODUCTION METHODS OF MAYENITE CATALYST SUPPORTS
}

\author{
MANERA $\mathrm{C}^{1}$, PERONDI D ${ }^{1}$, TONELLO AP ${ }^{1}$, KERWALD J ${ }^{1}$, BARCELLOS $\mathrm{T}^{2} \mathrm{e}$ \\ GODINHO $\mathrm{M}^{1}$ \\ ${ }^{1}$ University of Caxias do Sul, Graduate Program in Engineering Processes and Technologies \\ ${ }^{2}$ University of Caxias do Sul, Graduate Program in Biotechnology \\ E-mail contact: cmanera1@ucs.br
}

\begin{abstract}
The interesting catalytic properties of mayenite, related to its particular crystal structure, makes it suitable for use in catalyst synthesis. The objective of this study is to evaluate different preparation methods of a mayenite catalyst support. Three methods were studied (solid mixing in a high energy mill, solid mixing in a conventional ball mill and hydrothermal method) and samples were characterized by phase identification (XRD) and textural properties. The results showed that single phase mayenite $\left(S_{B E T} 30.3 \mathrm{~m}^{2} / \mathrm{g}\right)$ can be produced by high energy milling method. On the other hand, mayenite with a specific surface area of $57.0 \mathrm{~m}^{2} / \mathrm{g}$ can be produced by the simple method of conventional ball milling. However, other phases were present in the sample. Mayenite produced was found to be promising for application as support on catalyst production.
\end{abstract}

\section{INTRODUCTION}

The mineral mayenite was originally reported from the Eifel volcanic complex in Germany and was named due to the place of its discovery, Mayen (Germany). It is one of the intermediate phases of the $\mathrm{CaO}-\mathrm{Al}_{2} \mathrm{O}_{3}$ binary system, stoichiometrically represented as $\mathrm{Ca}_{12} \mathrm{Al}_{14} \mathrm{O}_{33}$. Mayenite was historically studied as a common phase present in Portland cement and has recently enjoyed renewed research interest due to the discovery of oxygen mobility, ionic conductivity (SCHMIDT et al., 2014) and sorbent properties (CUCCINIELLO et al., 2017). Mayenite has also been used as catalyst support for tar cracking in biomass gasification (LI et al., 2009). According to Schmidt et al. (2014), mayenite presents a quite uncommon crystal structure that may be described as some kind of anti-zeolite, as it forms positively charged cage-like structures, partially occupied by anions. Mayenite, also written as C12A7 $\left(12 \mathrm{CaO} \cdot 7 \mathrm{Al}_{2} \mathrm{O}_{3}\right)$ is a complex oxide of $\mathrm{Ca}$ and $\mathrm{Al}$ whose stoichiometric cubic unit cell is expressed as $\left[\mathrm{Ca}_{24} \mathrm{Al}_{28} \mathrm{O}_{64}\right]^{4+} \cdot 2 \mathrm{O}^{2-}$ where 64 of the 66 oxygen ions per unit cell are fixed in a $\mathrm{Ca}-\mathrm{Al}-\mathrm{O}$ framework forming 12 "cages", while the other two oxygen ions are distributed within the cages (LI et al., 2009). These oxygen atoms are often described as "free" or "extraframework" oxygen, as they are only lightly bound (SCHMIDT et al., 2014).

The interesting catalytic properties of mayenite are related to its particular crystal structure and extra-framework oxygen. The latter, highly reactive species are responsible for migrating to the active site of catalyst (e.g. Ni, Co and Pt) and gasifying the deposited carbon 


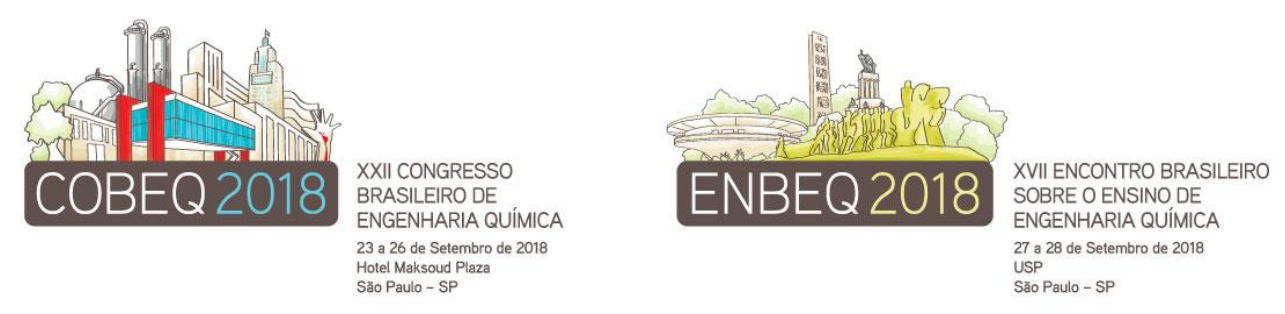

to $\mathrm{CO}$, preserving the deactivation of catalyst due to carbon deposition. Furthermore, a study performed by Li et al. (2009) showed that the free oxygen in the structure of the catalysts can be replaced by sulfur, extending the catalyst life time in the presence of $\mathrm{H}_{2} \mathrm{~S}$. Despite its suitable catalytic properties, the conventional method of mayenite production (solid state reaction) needs high reaction temperatures and long reaction times. Moreover, the high temperatures used lead to a drastic reduction in the specific surface area of mayenite. Therefore it is crucial to understand the influence of the production method in the final properties of mayenite. The objective of this study is to evaluate different preparation methods of a mayenite catalyst support by means of its textural properties and phase identification.

\section{MATERIALS AND METHODS}

Mayenite was produced from $\mathrm{Ca}(\mathrm{OH})_{2}$ (purity > 95\%) and $\mathrm{Al}(\mathrm{OH})_{3}$ (purest) bought from Cinética Reagents \& Solutions. Initially, the precursors were mixed in stoichiometric ratio (6:7) and the mixture was used in the different production methods described in the following sections.

\subsection{Solid Mixing Method in a High Energy Mill}

In the high energy mill method, $13 \mathrm{~g}$ of the precursors were grounded in a high energy planetary ball mill (Retsch, Emax) for $10 \mathrm{~min}$ at a grinding rate of $1000 \mathrm{rpm}$. Another sample was produced in the high energy mill under the same conditions, except the grinding rate defined as $400 \mathrm{rpm}$.

\subsection{Solid Mixing Method in a Conventional Ball Mill}

A conventional stainless steel ball mill was used to mix about $350 \mathrm{~g}$ of precursors at a grinding rate of $47 \mathrm{rpm}$. The mixture was kept for $24 \mathrm{~h}$.

\subsection{Hydrothermal Method}

Mayenite was prepared following the method proposed by Cucciniello et al. (2017). According to the method, $10 \mathrm{~g}$ of precursors were added to $100 \mathrm{~mL}$ of distilled water and grounded under magnetic stirring for $4 \mathrm{~h}$ at $25{ }^{\circ} \mathrm{C}$. Then, the mixture was placed in an autoclave at $150{ }^{\circ} \mathrm{C}$ for $5 \mathrm{~h}$. The obtained solid was filtered and dried at $105^{\circ} \mathrm{C}$ overnight.

After the procedures, samples from high energy mill method (400 and $1000 \mathrm{rpm}$ ), conventional ball mill method and hydrothermal method were calcined at $1000{ }^{\circ} \mathrm{C}$ in air for 4h. Samples were named HEM400, HEM1000, CBM and HM, respectively.

\subsection{Characterization}

X-ray powder diffraction (XRD): Samples were investigated by X-ray diffraction analysis (Shimadzu X-ray diffractometer, XRD 6000) in the $2 \theta$ range of $5-90^{\circ}$ with the resolution of $0.05^{\circ}$. 

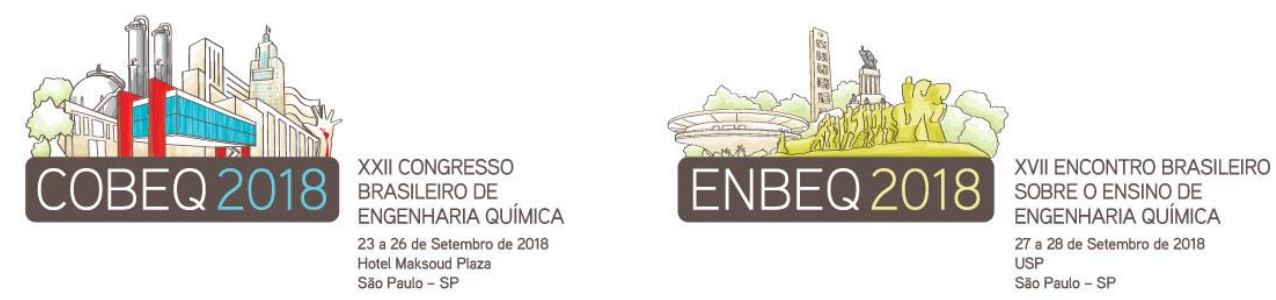

$\underline{\mathrm{N}_{2}}$ adsorption isotherms: Specific surface area, total pore volume and average pore diameter were characterized by $\mathrm{N}_{2}$ adsorption at $77 \mathrm{~K}$ in a Surface Area and Pore Size Analyzer (Quantachrome, Nova 1200). Prior to analysis, samples were outgassed under vacuum at $380{ }^{\circ} \mathrm{C}$ for $20 \mathrm{~h}$.

\section{RESULTS AND DISCUSSION}

The XRD patterns of the materials prepared by the described methods are shown in Figure 1. It is clear from the figure that mayenite was successfully produced by the 4 methods studied. In addition, sample HEM1000 presented only $\mathrm{Ca}_{12} \mathrm{Al}_{14} \mathrm{O}_{33}$ phase while $\mathrm{CaO}$ and $\mathrm{CaAl}_{4} \mathrm{O}_{7}$ phases were observed in the other samples. Furthermore, mayenite produced by HEM1000 method presented the highest crystallinity according to the highest intensity of the peaks (LI et al., 2009). The high concentration of $\mathrm{CaO}$ observed in the HEM400 sample, indicates that the lowest grinding rate was not appropriate.

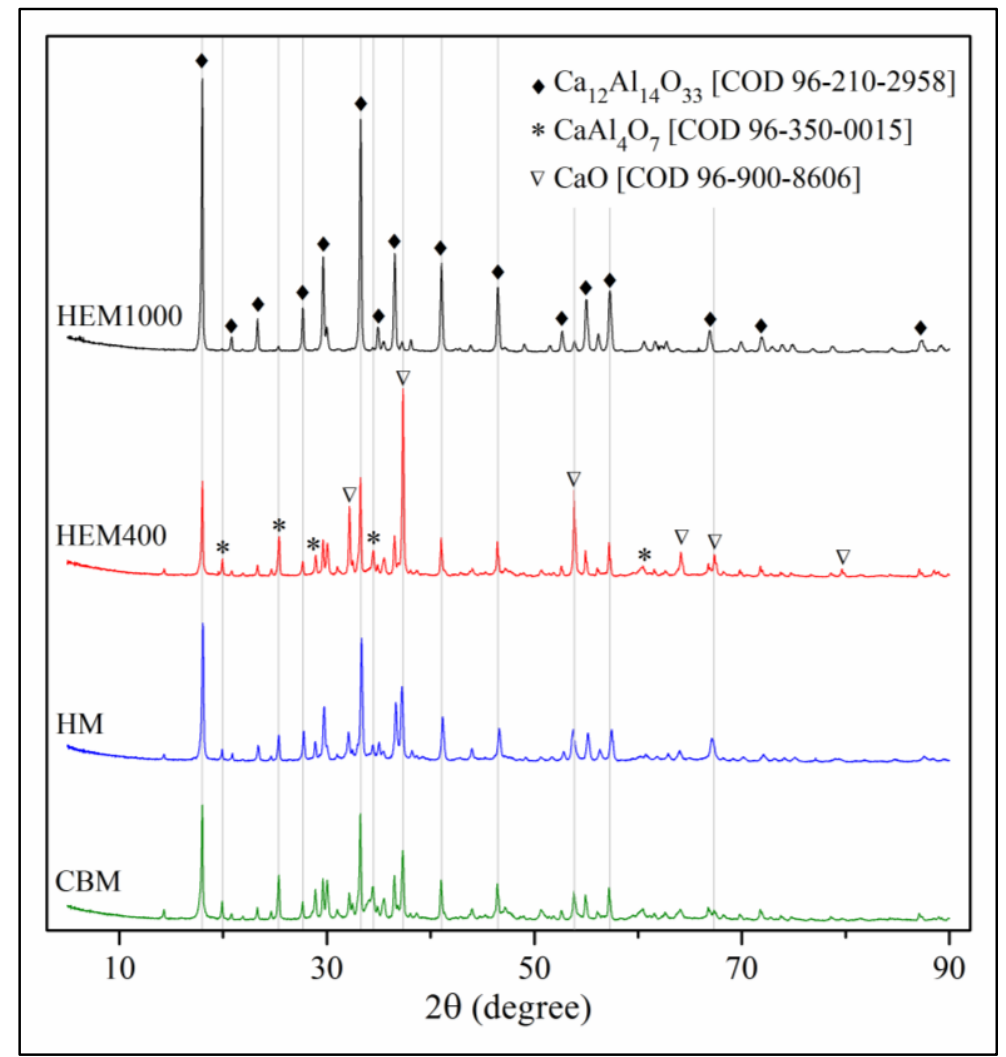

Figure 1 - XRD patterns of mayenite from different preparation methods

The $\mathrm{CaO}$ phase (pure $\mathrm{Ca}$ ) and $\mathrm{CaAl}_{4} \mathrm{O}_{7}$ phase (Al-rich phase) observed in the samples may be an indicative of insufficient mixing of reagents. According to Iftekhar et al. (2008), $\mathrm{CaAl}_{4} \mathrm{O}_{7}$ is a more unreactive phase of Ca-Al-O system. Therefore, once formed, it is difficult to continue reacting to the formation of $\mathrm{Ca}_{12} \mathrm{Al}_{14} \mathrm{O}_{33}$. The presence of $\mathrm{CaO}$ was also reported by Ozawa et al. (2011) in a mayenite produced by the sol-gel method and calcined at $900{ }^{\circ} \mathrm{C}$. Textural properties of mayenite samples are presented in Table 1. It is well known that higher surface areas are related to larger pore volumes and/or smaller pore diameters. HEM1000 presented the lowest surface area due to the fact that the sample had lower pore volume and 


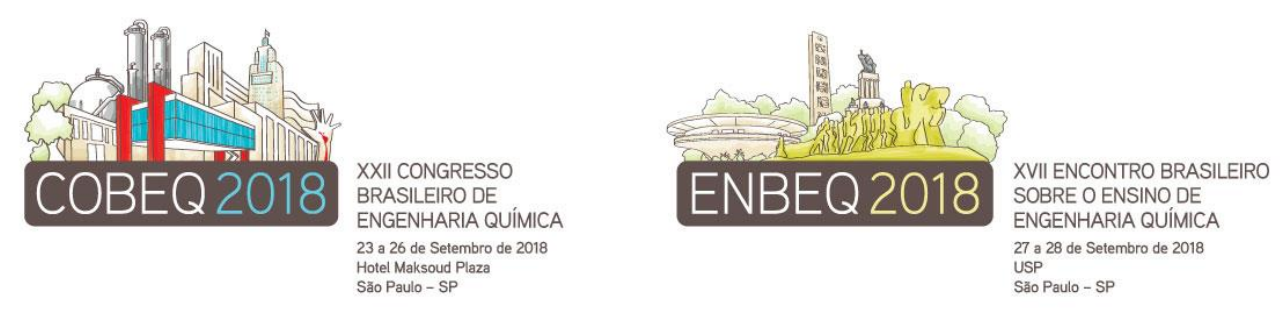

its pores had a larger average diameter, as can be observed in Table 1.

Table 1 - Textural properties of mayenite from different preparation methods

\begin{tabular}{cccc}
\hline Samples & $\mathrm{S}_{\text {BET }}\left(\mathrm{m}^{2} / \mathrm{g}\right)$ & $\mathrm{V}_{\mathrm{P}}\left(\mathrm{cm}^{3} / \mathrm{g}\right)$ & $\mathrm{D}_{\mathrm{P}}(\mathrm{nm})$ \\
\hline HEM1000 & 30.3 & 0.065 & 8.6 \\
HEM400 & 50.9 & 0.079 & 6.2 \\
CBM & 57.0 & 0.109 & 7.9 \\
HM & 40.5 & 0.079 & 7.6 \\
\hline
\end{tabular}

The larger surface area $\left(57.0 \mathrm{~m}^{2} / \mathrm{g}\right)$ obtained for CBM can be attributed mainly to its high total pore volume. According to Ozawa et al. (2011), catalysts usually present specific surface area in the range of 30 to $130 \mathrm{~m}^{2} / \mathrm{g}$. Thus, in view of the surface area, mayenite samples produced in this work can be used as support for the production of catalysts for gasification processes.

\section{CONCLUSIONS}

Mayenite $\left(\mathrm{C}_{12} \mathrm{Al}_{14} \mathrm{O}_{33}\right)$ was successfully synthesized by different methods. Single phase mayenite with $30.3 \mathrm{~m}^{2} / \mathrm{g}$ was produced by high energy milling method with a short mixing time (10 min). The simple method of conventional ball milling allowed mayenite production, however other phases (i.e. $\mathrm{CaO}, \mathrm{CaAl}_{4} \mathrm{O}_{7}$ ) were present in the synthesized sample. Finally, the four studied methods proved to be suitable for the production of mayenite support with different qualities for use in catalyst synthesis.

\section{REFERENCES}

CUCCINIELLO, R.; INTISO, A.; CASTIGLIONE, S.; GENGA, A.; PROTO, A. Total oxidation of trichloroethylene over mayenite ( $\left.\mathrm{Ca}_{12} \mathrm{Al}_{14} \mathrm{O}_{33}\right)$ catalyst. Appl. Catal. B, v. 204, p. 167-172, 2017.

IFTEKHAR, S.; GRINS, J.; SVENSSON, G.; LÖÖF, J.; JARMAR, T.; BOTTON, G. A.; ANDREI, C. M.; ENGQVIST, H. Phase formation of $\mathrm{CaAl}_{2} \mathrm{O}_{4}$ from $\mathrm{CaCO}_{3}-\mathrm{Al}_{2} \mathrm{O}_{3}$ powder mixtures. J. Eur. Ceram. Soc., v. 28, n. 4, p. 747-756, 2008.

LI, C.; HIRABAYASHI, D.; SUZUKI, K. A crucial role of $\mathrm{O}_{2}{ }^{-}$and $\mathrm{O}_{2}{ }^{2-}$ on mayenite structure for biomass tar steam reforming over Ni/Ca12 $\mathrm{Al}_{14} \mathrm{O}_{33}$. Appl. Catal. B, v. 88, p. 351-360, 2009.

OZAWA, K.; SAKAMOTO, N.; WAKIYA, N.; SUZUKI, H. Fabrication of $12 \mathrm{CaO} \cdot 7 \mathrm{Al}_{2} \mathrm{O}_{3}$ powders with high specific surface area by sol-gel and ball-milling method. J. Ceram. Soc. Jpn., v. 119, n. 1390, p. 460-463, 2011.

SCHMIDT, A.; LERCH, M.; EUFINGER, J. P.; JANEK, J.; TRANCA, I.; ISLAM, M. M.; BREDOW, T.; DOLLE, R. Chlorine ion mobility in Cl-mayenite $\left(\mathrm{Ca}_{12} \mathrm{Al}_{14} \mathrm{O}_{32} \mathrm{Cl}_{2}\right)$ : An investigation combining high-temperature neutron powder diffraction, impedance spectroscopy and quantum-chemical calculations. Solid State Ionics, v. 254, p. 48-58, 2014. 